Киричко Б. П., доктор ветеринарних наук, Звенігородська Т. В., аспірант *

Полтавська державна аграрна академія

Парченко В. В., кандидат фармацевтичних наук

Запорізький державний медичний університет

\title{
ВИВЧЕННЯ ПРОТИМІКРОБНОЇ ДІЇ НОВИХ ПОХІДНИХ 1,2,4-ТРИАЗОЛУ
}

\section{Рецензент - доктор ветеринарних наук, професор В. П. Бердник}

\begin{abstract}
Досліджена протимікробна дія нових похідних 1,2,4-триазолу - сполук АИ 99 та АИ 100. Визначення чутливості мікроорганізмів до вказаних сполук проводили методом дифузії в атар із використанням спеціально виготовлених дисків. Встановлено, шо протимікробна дія сполук АИ 99 та АИ 100 виявлясться в 0,5-1\% конщентраиії.

Найвираженішу антимікробну дію сполуки АИ $99 i$ АИ 100 мають проти Corinobacter pseu-

dodiphteridicum, Str. pyogenes, ma Staph. spp., а слабку - по відношенню до P. vulgaris i E. coli.
\end{abstract}

Ключові слова: похідні триазолу, сполуки АИ 99, АИ 100, антимікробна активність.

Постановка проблеми. Похідні 1,2,4триазолу, як потенційно біологічно активні сполуки, викликають неабиякий інтерес серед науковців фармацевтичної галузі.

Різнобічна біологічна дія поряд із незначною токсичністю створюють підгрунтя для отримання нових сполук із вираженою фармакологічною активністю.

Тому ми вважали за доцільне синтезувати i вивчити біологічну активність деяких похідних 1,2,4-триазол-3-тіону [2-4, 6-8].

Аналіз основних досліджень і публікацій, у яких започатковано розв'язання проблеми. Взагалі у ветеринарній практиці при місцевому лікуванні гнійно-запальних процесів широко застосовуються антибіотики, сульфаніламідні препарати у поєднанні з місцевою хірургічною обробкою і фізіотерапевтичними процедурами.

Ïх використання дозволяє усунути основний етіологічний фактор - патогенну мікрофлору, але не завжди забезпечує високу терапевтичну ефективність.

Крім того, в умовах підвищення резистентності гноєрідної мікрофлори та зміненої реактивності організму місцеве лікування ран наявними засобами стає все більш складною проблемою [1].
Усе це вимагає постійного удосконалення й оновлення лікарських засобів, що використовуються у ветеринарній практиці [1].

Мета досліджень та методика їх проведення. Метою дослідження було з'ясування протимікробної дії нових потенційно біологічно активних сполук, похідних 1,2,4-триазолу.

Дослідження проводилися в умовах центральної бактеріологічної лабораторії м. Полтава.

Тестуванню щодо антимікробної активності піддавалися сполуки АИ 99 та АИ 100 у формі $0,1 \%, 0,2 \%, 0,5 \%$ та $1 \%$ водних розчинів.

Визначення чутливості мікроорганізмів до вказаних сполук проводили методом дифузії в aгар із використанням спеціально виготовлених дисків.

У якості тест-культур використовували 18-годинні агарові чи бульйонні культури Str. pyogenes, Staph. spp., E. coli (O 5922), P. vulgaris, Corinobacter pseudodiphteridicum, Pseudomonas aeruginosa, Salmonella spp., Candida spp., що засівалися на середовище Мюллера-Хінтона.

Мікроорганізми вважали чутливими до тестованих сполук у разі наявності зони затримки мікробного росту більше ніж 10 мм [5].

Результати досліджень. Результати 3 визначення чутливості мікроорганізмів до запропонованих нами сполук наведені в таблиці.

Iз наведених даних видно, що тестовані нами сполуки АИ 99 та АИ 100 виявляють протимікробну дію тільки в $0,5 \%$ та $1 \%$ концентраціях. При цьому найчутливішими виявилися Corinobacter pseudodiphteridicum, Str. pyogenes та Staph. spp.

Слабку протимікробну дію сполуки виявляли по відношенню до P. vulgaris i E. coli.

Взагалі нечутливими до тестованих сполук виявилися Pseudomonas aeruginosa, Salmonella spp. тa Candida spp.

* Керівник - доктор ветеринарних наук Б. П. Киричко 
Результати визначення чутливості мікроорганізмів до тестованих сполук

\begin{tabular}{|c|c|c|c|c|c|c|c|c|}
\hline \multirow{3}{*}{ Мікроорганізми } & \multicolumn{8}{|c|}{ Зона затримки росту, мм } \\
\hline & \multicolumn{4}{|c|}{ АИ 99} & \multicolumn{4}{|c|}{ АИ 100} \\
\hline & $0,1 \%$ & $0,2 \%$ & $0,5 \%$ & $1 \%$ & $0,1 \%$ & $0,2 \%$ & $0,5 \%$ & $1 \%$ \\
\hline Str. pyogenes & - & - & - & 12 & - & - & 9 & 14 \\
\hline Staph. spp. & - & - & - & 14 & - & - & 14 & 16 \\
\hline E. coli (O 5922) & - & - & - & 11 & - & - & 9 & 9 \\
\hline P. vulgaris & - & - & - & 10 & - & - & - & 7 \\
\hline Corinobact. pseudodipht. & - & - & - & 22 & - & - & 11 & 19 \\
\hline Pseudomonas aeruginosa & - & - & - & - & - & - & - & - \\
\hline Salmonella spp. & - & - & - & - & - & - & - & - \\
\hline Candida spp. & - & - & - & - & - & - & - & - \\
\hline
\end{tabular}

\section{Висновки:}

1. Протимікробна дія сполук АИ 99 та АИ 100 виявляється в концентрації 0,5 і $1 \%$.

2. Найвираженішою антимікробною дією спо-

\section{БІБЛІОГРАФІЯ}

1. Алексеева И. В. Новые разработки для лечения животных при гнойно-воспалительных процессах / И. В. Алексеева // Ветеринария. - 2006. № 5. - C. 52-56.

2. Каплаушенко А. Г. Синтез, перетворення і біологічна активність в ряду 5-[2-,(3-,4-)нітрофеніл]-2,4-дигідро-1,2,4-тріазоліл-3-тіонів / А. Г. Каплаушенко, С. Г. Книш, О. І. Панасенко // Мед. хімія. - 2005. - Т. 7, № 3. - С. 98-101.

3. Киричко Б. П. Вивчення антиоксидантної активності деяких похідних 1,2,4-триазолу / Б. П. Киричко // Вісник Полтавської державної аграрної академії. - 2007. - № 2. - С. 125-126.

4. Киричко Б. П. Действие препаратов - производных триазола на клинико-биохимический статус животных / Б. П. Киричко, Е. Г. Кныш, В. В. Парченко // Сельскохозяйственная биология. - 2008. - № 2. - С. 98-102.

5. Лабинская A. С. Микробиология с техникой микробиологических исследований / А. С. Лабинская. - М.: Медицина, 1978. - 394 с.

6. Парченко $B$. $B$. Изучение противомикробной и луки АИ 99 і АИ 100 володіють проти Corinobacter pseudodiphteridicum, Str. pyogenes та Staph. spp.

противогрибковой активности некоторых производных 5-гетерил-2,4-дигидро-1,2,4-триазол-3-тионов, 2-бензилиден-1,2,4-триазоло-(3,4-В)-тиазол-3-(2Н)ионов и бензилиден-гидразидов-5-гетарил-2,4дигидро-1,2,4-триазол-3-меркаптоуксусных кислот / В. В. Парченко, Ю. В. Маковик, Е. Г. Кныш // Актуальні питання фармац. та мед. науки та практики. - Запоріжжя, 2004. - Вип. XII. - С. $72-$ 76.

7. Парченко В. В. Синтез и биологическая активность некоторых производ-ных 5-фуран-2-ил-4фенил-2,4-дигидро-1,2,4-тріазол-3-тионов / В. В. Парченко, Ю. В. Маковик, Е. Г. Кныш // Актуальні питания фармац. та мед. науки та практики. - Запоріжжя, 2005. - Вип. XIV. - С. 263-266.

8. Синтез, фізико-хімічні властивості та біологічна активність солей 2-(5-R'-4-R-1,2,4-триазол-3ілтіо)ацетатних кислот / О. I. Панасенко, С. Г. Книш, В. В. Парченко, А. Г. Каплаушенко, А. С. Гоцуля, Ю. В. Маковик, С. М. Куліш, В. Й. Іздепський, Б. П. Киричко // Вісник Полтавської державної аграрної академії. - 2007. - № 3. - С. 27-28. 